\title{
SEX REWARDED, SEX PUNISHED
}

A STUDY OF THE STATUS “FEMALE SLAVE” IN EARLY JEWISH LAW 


$$
\text { Judaism and Jewish Life }
$$

Geoffrey Alderman (University of Buckingham, England)

Meir Bar-Ilan (Bar-Ilan University, Israel)

Herbert Basser (Queen's University, Canada)

Donatella Ester Di Cesare (Universita La Sapienza, Italy)

Simcha Fishbane (Touro College, New York), Series Editor

Andreas Nachama (Touro College, Berlin)

Ira Robinson (Concordia University, Montreal)

Nissan Rubin (Bar-Ilan University, Israel)

Susan Starr Sered (Suffolk University, Boston)

Reeva Spector Simon (Yeshiva University, New York)

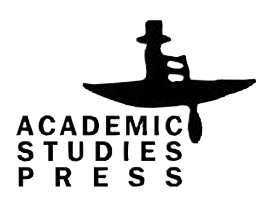




\section{SEX REWARDED \\ SEX PUNISHED}

\section{A STUDY OF THE STATUS "FEMALE SLAVE” IN EARLY JEWISH LAW}

(final editing and preparation for publication by Tirzah Meacbam leBeit Yoreb) 
Kriger, Diane.

Sex rewarded, sex punished : a study of the status 'female slave' in early Jewish law / Diane Kriger.

p. cm. -- (Judaism and Jewish life)

Includes bibliographical references and index.

ISBN 978-1-934843-48-2 (hardback)

1. Women (Jewish law) 2. Women slaves (Jewish law) 3. Women in the Bible. I. Title.

KBM526.K75 2011

296.086'25--dc22

2010054363

Copyright (C) 2011 Academic Studies Press

All rights reserved

ISBN 978-1-934843-48-2

Book design by Olga Grabovsky

On the cover: Abrabam Sends Hagar and Ishmael Away, by Gustave Doré, 1866.

Published by Academic Studies Press in 2011

28 Montfern Avenue

Brighton, MA 02135, USA

press@academicstudiespress.com

www.academicstudiespress.com

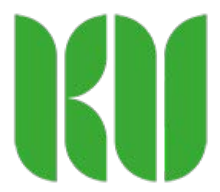

An electronic version of this book is freely available, thanks to the support of libraries working with Knowledge Unlatched. KU is a collaborative initiative designed to make high quality books Open Access for the public good. The Open Access ISBN for this book is 978-1-644-69329-2. More information about the initiative and links to the Open Access version can be found at www.knowledgeunlatched.org.

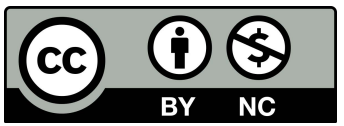

Effective March 20, 2020, this book is subject to a CC-BY-NC license. To view a copy of this license, visit https://creativecommons.org/licenses/by-nc/4.0/. Other than as provided by these licenses, no part of this book may be reproduced, transmitted, or displayed by any electronic or mechanical means without permission from the publisher or as permitted by law. 
I wish to dedicate this work to the memories of three individuals who bave also inspired me with their courage:

Imi Shirley Rachel Movshovitz Kriger, ל", bat Mordechai and Chanab

Judith Leah Ain, ל"ז, bat Avraham and Malkab

Lynne Mary Wheller, B.A., 1961-1996 
